\title{
Protoplast isolation, transient transformation of leaf mesophyll protoplasts and improved Agrobacterium-mediated leaf disc infiltration of Phaseolus vulgaris: tools for rapid gene expression analysis
}

\author{
Kalpana Nanjareddy ${ }^{1}$, Manoj-Kumar Arthikala ${ }^{1}$, Lourdes Blanco ${ }^{1,2}$, Elizabeth S. Arellano ${ }^{3}$ and Miguel Lara ${ }^{1,4^{*}}$ (D)
}

\begin{abstract}
Background: Phaseolus vulgaris is one of the most extensively studied model legumes in the world. The P. vulgaris genome sequence is available; therefore, the need for an efficient and rapid transformation system is more imperative than ever. The functional characterization of $P$. vulgaris genes is impeded chiefly due to the non-amenable nature of Phaseolus sp. to stable genetic transformation. Transient transformation systems are convenient and versatile alternatives for rapid gene functional characterization studies. Hence, the present work focuses on standardizing methodologies for protoplast isolation from multiple tissues and transient transformation protocols for rapid gene expression analysis in the recalcitrant grain legume $P$. vulgaris.

Results: Herein, we provide methodologies for the high-throughput isolation of leaf mesophyll-, flower petal-, hypocotyl-, root- and nodule-derived protoplasts from P. vulgaris. The highly efficient polyethylene glycol-mannitol magnesium (PEG-MMG)-mediated transformation of leaf mesophyll protoplasts was optimized using a GUS reporter gene. We used the P. vulgaris SNF1-related protein kinase 1 (PVSnRK1) gene as proof of concept to demonstrate rapid gene functional analysis. An RT-qPCR analysis of protoplasts that had been transformed with PvSnRK1-RNAi and PVSnRK1-OE vectors showed the significant downregulation and ectopic constitutive expression (overexpression), respectively, of the PVSnRK1 transcript. We also demonstrated an improved transient transformation approach, sonication-assisted Agrobacterium-mediated transformation (SAAT), for the leaf disc infiltration of $P$. vulgaris. Interestingly, this method resulted in a $90 \%$ transformation efficiency and transformed $60-85 \%$ of the cells in a given area of the leaf surface. The constitutive expression of YFP further confirmed the amenability of the system to gene functional characterization studies.

(Continued on next page)
\end{abstract}

\footnotetext{
* Correspondence: mlara@unam.mx

${ }^{1}$ Ciencias Agrogenómicas, Escuela Nacional de Estudios Superiores, Universidad Nacional Autónoma de México (UNAM), León C.P.37684, Guanajuato, Mexico

${ }^{4}$ Instituto de Biología, Universidad Nacional Autónoma de México (UNAM),

Ciudad Universitaria, Coyoacan, Ciudad de México C.P. 04510, Mexico

Full list of author information is available at the end of the article
}

\section{) Biomed Central}

(c) 2016 The Author(s). Open Access This article is distributed under the terms of the Creative Commons Attribution 4.0 International License (http://creativecommons.org/licenses/by/4.0/), which permits unrestricted use, distribution, and reproduction in any medium, provided you give appropriate credit to the original author(s) and the source, provide a link to the Creative Commons license, and indicate if changes were made. The Creative Commons Public Domain Dedication waiver (http://creativecommons.org/publicdomain/zero/1.0/) applies to the data made available in this article, unless otherwise stated. 
(Continued from previous page)

Conclusions: We present simple and efficient methodologies for protoplast isolation from multiple P. vulgaris tissues. We also provide a high-efficiency and amenable method for leaf mesophyll transformation for rapid gene functional characterization studies. Furthermore, a modified SAAT leaf disc infiltration approach aids in validating genes and their functions. Together, these methods help to rapidly unravel novel gene functions and are promising tools for $P$. vulgaris research.

Keywords: Agrobacterium infiltration, Gene expression, Overexpression, Phaseolus vulgaris, Protoplasts, RNAi, SnRK1, Sonication, Transient transformation

\section{Background}

The common bean, Phaseolus vulgaris, is an economically important crop that belongs to the family Leguminosae and is the most essential grain legume for direct human consumption in the world; in Latin America alone, this species holds a stake of more than $70 \%$ [1]. Despite having such enormous agroeconomic relevance, this crop suffers from several widespread major diseases and abiotic stresses, which decrease the crop yield $[2,3]$. Attempts at transformation and crop improvement programs have been hampered by this species' notorious recalcitrance to routine in vitro regeneration and transformation [4]. Furthermore, unlike other legumes, $P$. vulgaris has serious limitations, such as an unavailability of mutants and a lack of rapid and efficient tools for transformation, preventing this species from being used as a versatile model for legume-related research. The $P$. vulgaris genome sequence is available [5]; therefore, the need for an efficient and rapid transformation system is more imperative than ever. Although some reports have suggested the feasibility of the stable transformation of common bean using a microprojectile bombardment method [6], this option demands vast resources and intensive work with a miniscule yield compared to the bombardment methods of other model crop plants, including cereals [7]. Such a low efficiency makes this method potentially unusable in small-scale laboratories. As an alternative, the hairy root system is the only adoptable technique available to carry out transient gene functional analysis [8]. Nevertheless, this method is a transformation procedure that demands time and it is not eligible for a high-throughput analysis of heterologous gene expression.

Compared to the stable transgenic approach, the use of transient gene expression assays offers an opportunity to rapidly assess the function of a large number of genes by evaluating the transcriptional activity of promoters and the sub-cellular localization of proteins and to investigate cell biology and physiology, cell wall traits, etc. In plant biology research, protoplast transfection is well established and used efficiently in single-cell-based studies. Plant protoplasts have shown reactions similar to those of intact cells to hormones, metabolites, environmental cues and pathogen-derived elicitors, providing a powerful and versatile cell system for the high-throughput dissection of plant signal transduction pathways in many plant species, such as Arabidopsis [9-11], maize and rice [12], Brassica [13], sunflower [14], Populus [15], Poinsettia [16] and palm [17]. On the other hand, the available protocols for $P$. vulgaris protoplast isolation from either cell suspension cultures [18] or cotyledonary leaves [19] are not amenable to transfection [20].

In addition, the Agrobacterium-mediated leaf disc infiltration method is another transient system that is routinely exploited in functional analyses of genes. Sonication-assisted Agrobacterium-mediated transformation (SAAT) involves subjecting plant tissue to a brief period of ultrasound in the presence of Agrobacterium. Unlike other transformation methods, this system has the potential to transform several cell layers and, furthermore, is an easy and reliable approach to carry out gene functional characterization studies $[10,21,22]$. The protocol is potentially suitable for a wide variety of molecular studies, including gene regulation, protein localization, tagged protein expression, chromatin immunoprecipitation, protein-protein interactions, bimolecular fluorescence complementation (BiFC), protein stability, etc. The simplicity of the protocol allows it to be used in other crop plants as well.

The present paper describes novel protocols for protoplast isolation from different $P$. vulgaris tissues, such as leaf mesophyll, flower petal, hypocotyl, root and nodule, that could be further used to perform rapid cell biology, physiology, and biochemical assays, among others. This study also presents a highly efficient polyethylene glycolmannitol magnesium (PEG-MMG)-mediated transformation protocol for P. vulgaris leaf mesophyll-derived protoplasts. To validate this method for gene expression studies, we used the $P$. vulgaris SNF1-related protein kinase 1 (PvSnRK1) gene [23]. SnRK genes are evolutionarily conserved metabolic sensors that undergo activation in response to decreased energy levels in eukaryotes. Plant SnRK1 is well characterized and shown to regulate the timing of embryo maturation in Arabidopsis, sucrose cleavage in potato [24, 25], and 
pollen development (due to the failure to incorporate sucrose into starch) in barley [26]. SnRK1 also interacts with ABA-dependent and ABA-independent pathways in legumes [27]. The non-conserved cDNA region and open reading frame (ORF) of $P$. vulgaris SnRK1 were cloned individually in RNAi and constitutive expression (overexpression) vectors and transfected into mesophyll-derived protoplasts for the downregulation and overexpression of $P \nu S n R K 1$ transcript, respectively. Furthermore, the concept of transient gene expression is met by providing a modified gene transformation approach, the SAAT, for the leaf disc infiltration of $P$. vulgaris. A $\beta$-glucuronidase (GUS)-based assay and the constitutive expression of yellow fluorescent protein (YFP) demonstrate the efficiency of Agrobacterium infiltration, T-DNA integration and expression.

\section{Results}

Optimization of protoplast isolation

Selection of suitable tissues for protoplast isolation and Agrobacterium leaf disc infiltration

To establish a rapid and suitable system for physiological, biochemical and functional studies of $P$. vulgaris, we aimed to isolate leaf mesophyll protoplasts from the terminal trifoliates of ten-day-old plants (Fig. 1a). Young, healthy and well-irrigated (with $\mathrm{B} \& \mathrm{D}$ nutrient solution) plants that were grown at $28{ }^{\circ} \mathrm{C}$ with $65 \%$ humidity were pre-requisites for obtaining intact and uniformly sized protoplasts $[10,18]$. Approximately 3 - to $6-\mathrm{mm}$ proximal and distal segments of individual leaf blades were removed before slicing the tissues for digestion. To isolate protoplasts from freshly bloomed flowers, the basal segments of standard and wing petals were excised before proceeding to digestion (Additional file 1A). To obtain hypocotyl- and root-derived protoplasts, 1- to 3-day-old and 3- to 4-dayold germinated seedlings (Additional file 1B-C), respectively, were the most appropriate for isolating intact protoplasts. Root tips of approximately 3-4 $\mathrm{mm}$ (Additional file 1C) served as good sources of root-derived protoplasts. Choosing the root nodule tissue for isolating Rhizobium-infected and uninfected cells was relatively easy, as mature nodules would be undoubtedly be the best source to obtain fully differentiated cells. Hence, nodules 18-21 days post inoculation (dpi) were used in this study (Additional file 1D). SAAT-mediated Agrobacterium leaf disc infiltration was highly efficient and successful using the second trifoliates from 10-day-old plants (Fig. 5a). While excising the leaf discs, the midribs were preferentially avoided. However, the size of the disc did not alter the transformation efficiency.
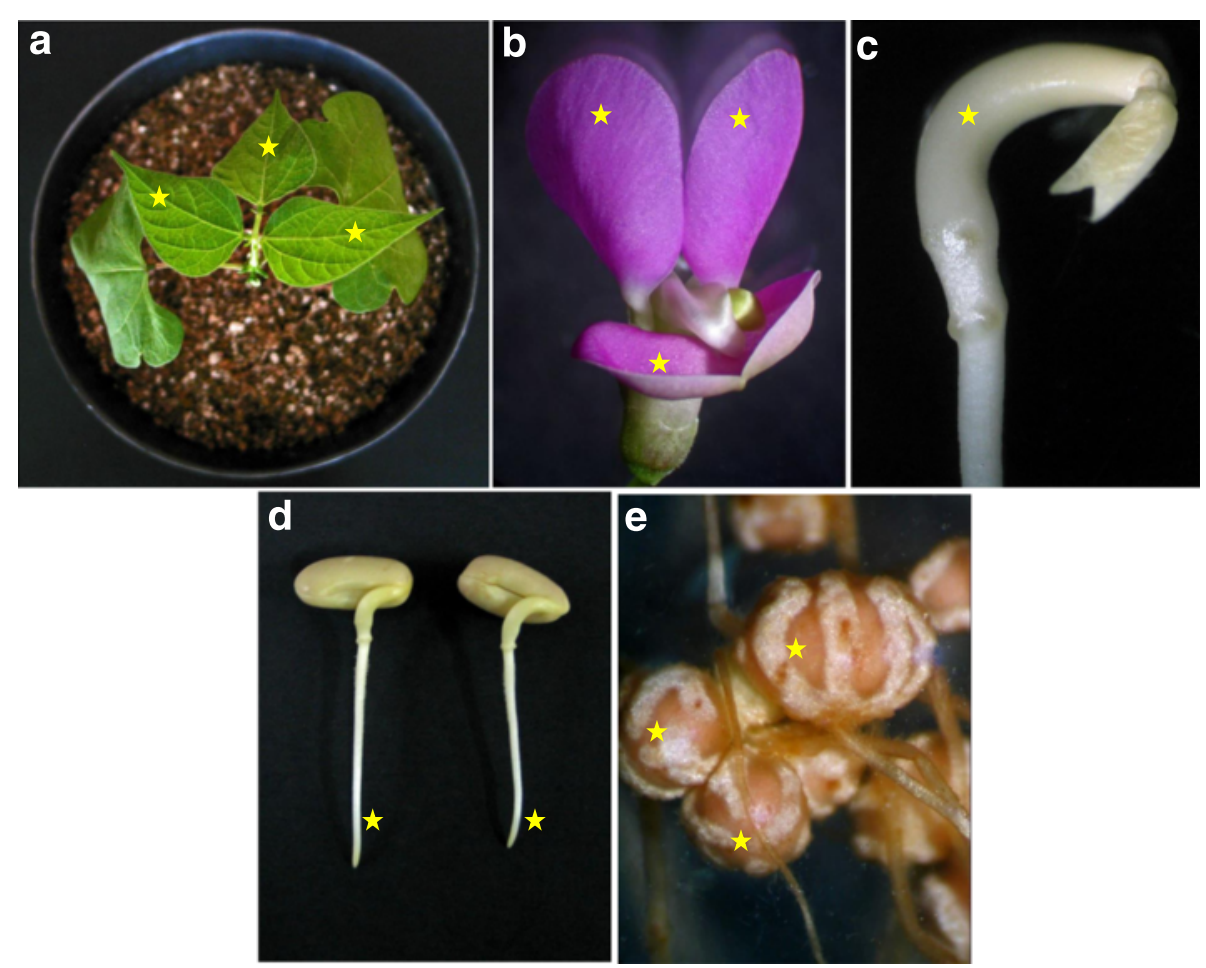

Fig. 1 Phaseolus vulgaris plant material for protoplast isolation. a Ten-day-old wild type plant showing the suitable trifoliate size. b Fully bloomed flowers ( 40 days after sowing) showing wing and keel petals. c Three-day-old decotyledoned germinated seed showing the appropriate stage of the hypocotyl. $\mathbf{d}$ The root tips of 3-day-old germinated seeds for root protoplast isolation. $\mathbf{e}$ The mature bean nodule 18-21 days after inoculation with Rhizobium tropici strain CIAT 899. Asterisks- the preferable portions of plant material for protoplast isolation 


\section{Isolation of protoplasts}

In the present work, we optimized protoplast isolation methods for P. vulgaris leaf mesophyll and flower petal with higher yield and efficiency. Table 1 provides a comprehensive overview of the enzyme combinations and conditions for obtaining protoplasts from multiple tissues. To obtain high yields of protoplasts, the leaf tissues were digested with enzyme solution I (ES-I), which contains cellulase and macerozyme. The enzyme concentrations of ES-I were $25 \%$ higher than the concentrations that are used for Arabidopsis leaf tissues [10]. The petals were digested with ES-II containing cellulase, macerozyme and pectinase. The tissues were vacuum treated for $30 \mathrm{~min}$ to ensure the proper infiltration of the enzyme solution into intercellular spaces to act on the cellulose, hemicelluloses and other cell wall components. A duration of $4-5 \mathrm{~h}$ was sufficient to complete the digestion of $P$. vulgaris leaf tissues; however, the petals were completely digested within 8-10 h. High protoplast yields of $3 \times 10^{5}$ cells $\mathrm{g}^{-1} \mathrm{ml}^{-1}$ fresh weight and $2 \times 10^{5}$ cells g ${ }^{-1} \mathrm{ml}^{-1}$ fresh weight were obtained from leaf mesophyll (Fig. 2a) and petal (Fig. 2b) tissues, respectively.

To digest the hypocotyl, root and nodule tissues, the tissues were first sliced and plasmolysed sequentially in $9 \%$ and $13 \%$ mannitol in CPW (Cell and protoplast washing solution) solution for $2 \mathrm{~h}$ each. Then, the plasmolysed hypocotyl and root tissues were treated with ES-III and the nodules tissues with ES-IV (Table 1) for a period of 16-18 h. Interestingly, the mechanical squeezing of the digesting tissues using sterile forceps further increased the protoplast yield. Nevertheless, the prolonged incubation of the samples did not affect the protoplast quality. These protocols were versatile and successful in obtaining high protoplast yields of $2 \times 10^{5}$ cells $\mathrm{g}^{-1} \mathrm{ml}^{-1} \mathrm{FW}$ from hypocotyls (Fig. 2c), roots, and nodules (Fig. $2 \mathrm{e}-\mathrm{g}$ ) and $1 \times 10^{5}$ cells $\mathrm{g}^{-1} \mathrm{ml}^{-1} \mathrm{FW}$ from the root tips (Fig. 2d).

A great variation in protoplast size was observed depending on the source. Hypocotyl-derived protoplasts were the largest (70 to $130 \mu \mathrm{m})$, and nodule-uninfected cell-derived protoplasts were the smallest ( 2 to $4 \mu \mathrm{m}$ )
(Fig. 2e \& c). The protoplasts mostly remained spherical, except in case of nodule-infected cells, which were heterogeneously shaped.

\section{Optimization of the transient transformation of leaf mesophyll-derived protoplasts}

To further exploit the isolated protoplasts for the functional analysis of genes, we used several methods to transform the leaf mesophyll protoplasts. Transformation approaches, such as electroporation [28, 29], heat shock, PEG mediated transformations, were tested using $20 \mu \mathrm{g}$ of plasmid DNA (pPZP-RCS-35S/intron GUS) and $2 \times 10^{5}$ leaf mesophyll protoplasts. The protoplasts that were transformed by electroporation showed $35.3 \pm 3.4 \%$ transformation efficiency, as determined by GUS staining (Fig. 3a; Additional file 2). Altering several factors, such as electrolytes, electric field and different capacitance for different durations ranging from 10 to $15 \mathrm{~s}$ could not significantly improve the transformation efficiency (data not shown). Heat shock also showed a low transformation efficiency ranging from $34.4 \pm 6.8 \%$.

PEG-mediated transformation was performed using two different buffers: 1) PEG-calcium transfection solution: 10-40 \% PEG 4000 in distilled water containing $0.2 \mathrm{M}$ mannitol and $100 \mathrm{mM} \mathrm{CaCl} 2$ [10] and 2) PEGMMG transfection solution: 10-40 \% PEG 4000 in MMG solution [30]. The efficiency was the highest in PEG-mediated transformation in solution with $40 \%$ PEG 4000 (Fig. 3a-b), where $93.4 \pm 1.8 \%$ of the protoplasts were transformed by the PEG-MMG method; only $65.8 \pm 3.8 \%$ of the protoplasts were transformed in PEG-calcium transfection solution (Fig. 3a \& Additional file 4). The concentration of plasmid DNA was the next important factor that influenced the transformation frequency [31]. Utilizing the PEG-MMG transformation approach herein, we analyzed different plasmid DNA quantities to determine the optimal quantity yielding the highest percent transformation. As shown in Fig. 3b, $72 \pm 2.1 \%$ transformation was observed using low plasmid DNA quantities, such as 5 and $10 \mu \mathrm{g}$. Similarly, high plasmid DNA quantities, i.e., 30 and $40 \mu \mathrm{g}$, also resulted in a range of $87 \pm 3.1 \%$ transformation. However,

Table 1 Conditions for protoplast isolation from various Phaseolus vulgaris tissues

\begin{tabular}{|c|c|c|c|c|c|c|}
\hline Plant sample & Enzym & solution (ES) & Vacuum infiltration & Plasmolysis & Digestion time & Efficiency \\
\hline Leaf & ES-I & $\begin{array}{l}1.50 \%(\mathrm{w} / \mathrm{v}) \text { cellulase R10, } 0.37 \%(\mathrm{w} / \mathrm{v}) \\
\text { macerozyme R10 }\end{array}$ & $30 \mathrm{~min}$ & N/A & $4-5 h$ & $\begin{array}{l}3 \times 10^{5} \\
\text { cells } \mathrm{g}^{-1} \mathrm{ml}^{-1} \mathrm{FW}\end{array}$ \\
\hline Flower petal & ES-II & $\begin{array}{l}1.50 \%(\mathrm{w} / \mathrm{v}) \text { cellulase R10, } 0.37 \%(\mathrm{~W} / \mathrm{v}) \\
\text { macerozyme R10, } 30 \mathrm{U} \text { pectinase }\end{array}$ & $30 \mathrm{~min}$ & N/A & $8-10 \mathrm{~h}$ & $\begin{array}{l}2 \times 10^{5} \\
\text { cells } \mathrm{g}^{-1} \mathrm{ml}^{-1} \mathrm{FW}\end{array}$ \\
\hline $\begin{array}{l}\text { Hypocotyl } \\
\& \text { root }\end{array}$ & ES-III & $\begin{array}{l}2.0 \%(\mathrm{w} / \mathrm{v}) \text { cellulase R10, } 0.3 \%(\mathrm{w} / \mathrm{v}) \\
\text { macerozyme R10, } 4.0 \%(\mathrm{w} / \mathrm{v}) \text { hemicellulase }\end{array}$ & N/A & $4 \mathrm{~h}$ & $16-18 \mathrm{~h}$ & $\begin{array}{l}2 \times 10^{5} \\
\text { cells } \mathrm{g}^{-1} \mathrm{ml}^{-1} \mathrm{FW}\end{array}$ \\
\hline Nodule & ES-IV & $\begin{array}{l}1.0 \%(\mathrm{w} / \mathrm{v}) \text { cellulase } \mathrm{R} 10,0.3 \%(\mathrm{w} / \mathrm{v}) \\
\text { macerozyme R10, } 1.0 \%(\mathrm{~W} / \mathrm{v}) \text { hemicellulase, } \\
30 \mathrm{U} \text { of pectinase }\end{array}$ & N/A & $4 \mathrm{~h}$ & $16-18 \mathrm{~h}$ & $\begin{array}{l}1 \times 10^{5} \\
\text { cells } \mathrm{g}^{-1} \mathrm{ml}^{-1} \mathrm{FW}\end{array}$ \\
\hline
\end{tabular}



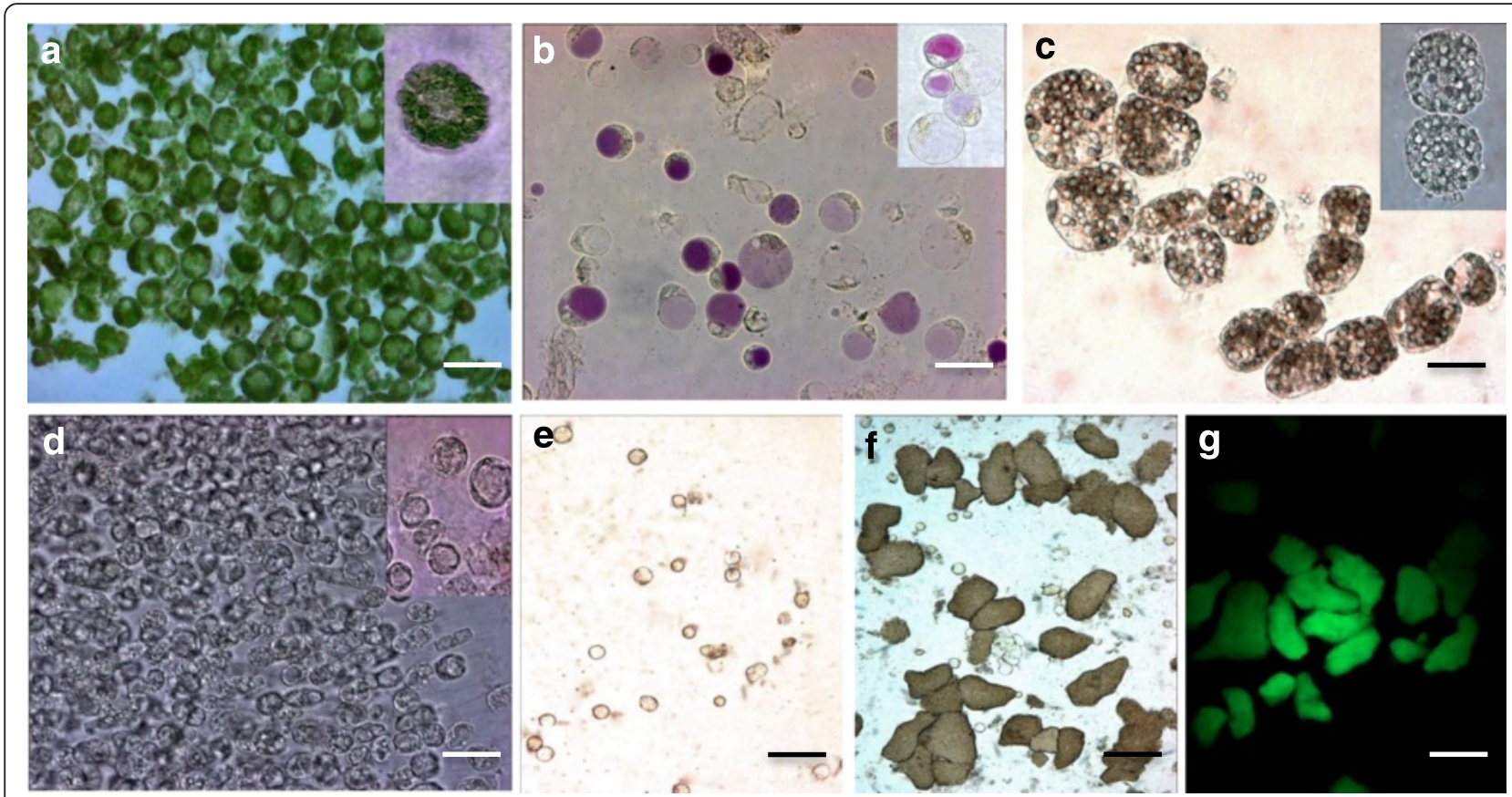

Fig. 2 Phaseolus vulgaris protoplasts that were isolated from multiple tissues: a Leaf mesophyll. b Flower petal. c Hypocotyl. d Root. e Uninfected nodule cells. f Rhizobium tropici-infected nodule cells. $\mathbf{g}$. tropici harboring the pSN30-GFP plasmid expressing the GFP protein in infected cells as seen under a laser-scanning confocal microscope. Scale bars: A, D-E, $15 \mu \mathrm{m} ; \mathrm{B}, 50 \mu \mathrm{m}$; and C, F-G, $100 \mu \mathrm{m}$

15-20 $\mu \mathrm{g}$ of plasmid DNA was suitable for achieving $92.5 \pm 2 \%$ transfection in all of the analyzed constructs (Fig. 3b).

\section{Gene functional analysis}

To further examine the feasibility of using $P$. vulgaris leaf mesophyll-derived protoplasts for the functional analysis of the genes, we explored the evolutionarily conserved $S n R K 1$ gene that is known to regulate energy and stress signaling in eukaryotes. To downregulate the $P v S n R K 1$ transcript, a plasmid harboring the PvSnRK1RNAi construct was transfected into leaf mesophyllderived protoplasts. Following $4-6 \mathrm{~h}$ of incubation, a fraction of cells was observed under a microscope to verify the expression of red fluorescence protein (RFP) from the transformed protoplasts (Fig. 4a-b). We then determined the percent transformation based on RFP expression; as expected, $92 \pm 2.1 \%$ of the protoplasts were transformed successfully. Furthermore, an RT-qPCR analysis of PvSnRK1-RNAi transformed protoplasts was performed to validate the downregulation of $P v S n R K 1$ expression. As depicted in Fig. 4c, the transcripts of PvSnRK1 significantly decreased by $58 \pm 3.2 \%$ in PvSnRK1-RNAi-transformed protoplasts compared to those in untransformed and control (transformed with an empty pTdT-RNAi vector) protoplasts. The overexpression of $P v S n R K 1$ was carried out under the constitutive 35S promoter ( $\mathrm{pH} 7 \mathrm{WG} 2 \mathrm{D}$ vector, henceforth called 'PvSnRK1-OE'). The transformed protoplasts were selected based on the green fluorescent marker (GFP) (Fig. 4d-e). Furthermore, these protoplasts showed a $91 \pm 1.8 \%$ transformation efficiency as determined by GFP-associated fluorescence. RT-qPCR analysis confirmed that $P \nu S n R K 1$ transcript accumulation in PvSnRK1-OE protoplasts significantly increased relative to that in untransformed and control protoplasts (Fig. 4f). The integration of the RNAi and overexpression constructs in the genome was further confirmed by the PCR amplification of the Tdt fragment (1430 bp) for RNAi and the $P v S n R K 1-35 \mathrm{~S}$ promoter (460 bp) and GFP (270 bp) for overexpression vectors (Additional file 3 ) in the transformed protoplasts. Taken together, these results demonstrate the suitability of using $P$. vulgaris mesophyll protoplasts for gene expression studies.

\section{Transient transformation of $P$. vulgaris leaf disc by an improved SAAT method}

Contrary to the direct transformation approach of mesophyll protoplasts (as demonstrated above), we also attempted to introduce an indirect transformation approach, SAAT [29], for the leaf disc infiltration of $P$. vulgaris (Fig. 5). The leaf disc infiltration assay was carried out using an improved SAAT method utilizing various infiltration media containing a bacterial density of $0.5-0.7$ at $\mathrm{OD}_{600}$. Among the tested infiltration media, $10 \mathrm{mM} \mathrm{MgCl} 2$ and a combination of $10 \mathrm{mM}$ $\mathrm{MgCl}_{2}$ and $5 \mathrm{mM}$ MES-KOH resulted in 30 and $50 \%$ of transfection efficiencies, respectively (Table 2). 

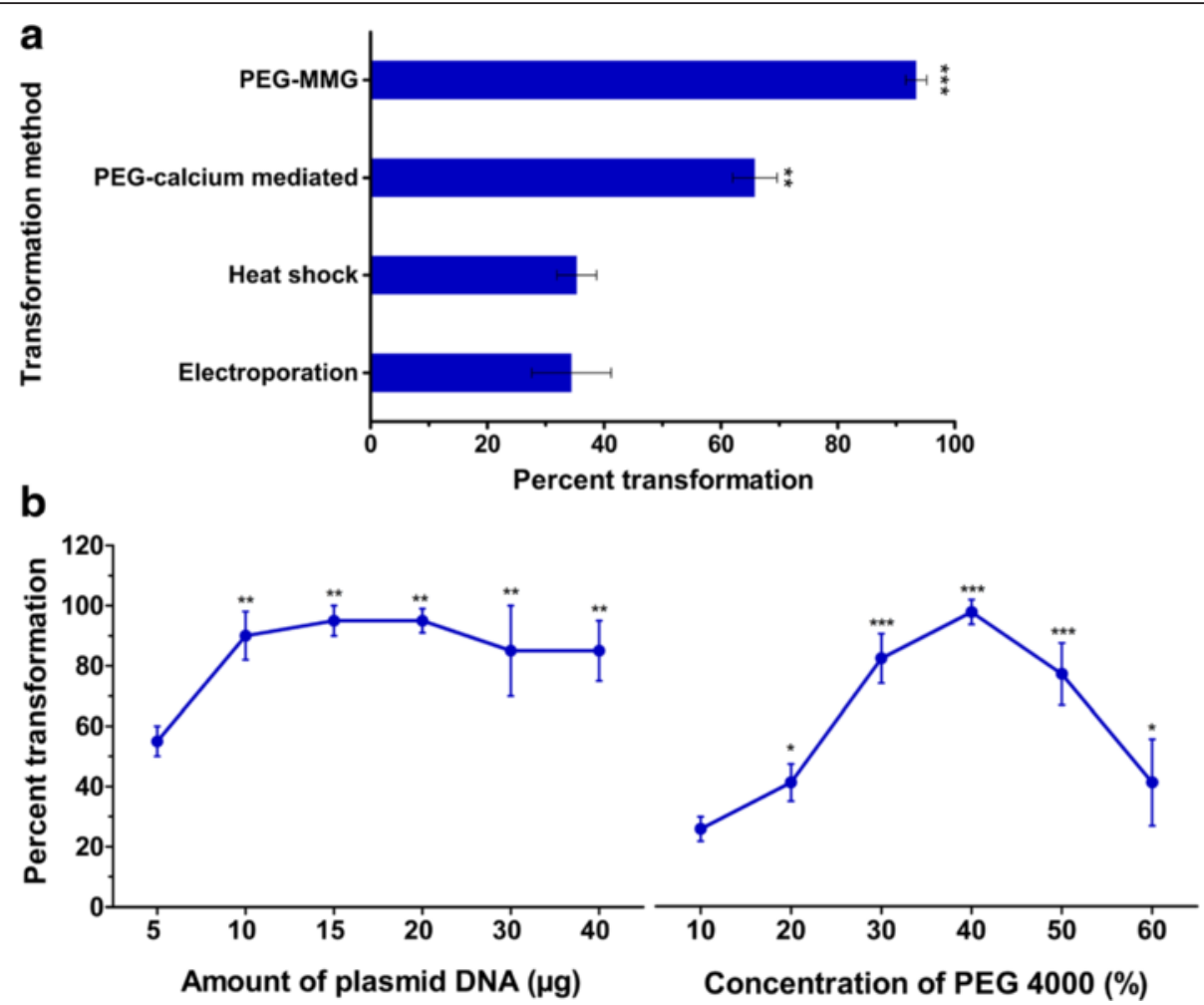

Fig. 3 Transformation efficiency of Phaseolus vulgaris leaf protoplasts by various transformation methods. a All of the experiments were performed using $20 \mathrm{\mu g}$ of plasmid DNA and $2 \times 10^{5}$ leaf mesophyll protoplasts. The graph shows the percent transformation efficiency in different transformation methods. $\mathbf{b}$ Percent transformation of protoplasts using various quantities of plasmid DNA (left) and different PEG 4000 (right) concentrations. The statistical significance of differences was determined using a one-way ANOVA Newman-Keuls Multiple Comparison Test $\left({ }^{*}, P<0.05 ;{ }^{* *}, P<0.01 ; *^{* *}, P<0.001\right)$. For both A and B, the data are the averages of three biological replicates $(n=9)$; the error bars represent means \pm SD

Interestingly, a high transfection efficiency of $90 \%$ was observed in Winan's AB infiltration medium amended with Silwet L-77 (OSi Specialities, Inc., Danbury, CT, USA) and acetosyringone prior to sonication (Table 2) because both Silwet L-77 and acetosyringone are important factors that improve transformation efficiency by increasing the DNA delivery and integration [32]. Microscopic observations of the GUS-stained leaf discs showed that $60-85 \%$ of cells on the leaf surface were transformed by the infiltration medium containing Silwet L-77 and acetosyringone (Fig. 5f).

To further validate the SAAT transient transformation, we utilized the pEarleyGate104 vector that constitutively expresses yellow fluorescent protein (YFP) in P. vulgaris leaf epidermal cells. The confocal images, as expected, showed strong YFP fluorescence in the cytoplasm of leaf epidermal cells (Fig. 6d). We previously showed using the same vector a similar expression pattern of YFP in $P$. vulgaris hairy roots [33]. In contrast, no fluorescence was observed in the leaf epidermal cells that were transformed with empty pEarleyGate104 vector (control) (Fig. 6a-b). Together, these results indicate the suitability of the modified SAAT leaf disc infiltration method to perform gene expression studies and that this method can be extended to studies using a variety of functional analyses, such as gene silencing, protein localization, promoter analysis, etc.

\section{Discussion}

The common bean, Phaseolus vulgaris, is a model legume that has been extensively studied worldwide. Given the absence of a reliable protocol for $P$. vulgaris regeneration, the development of an optimal in vitro culture system remains a major challenge because this and other species from the Phaseolus genus are recalcitrant for in vitro regeneration [20]. Thus, the application of biotechnological tools for crop improvement and gene functional characterization in $P$. vulgaris are major limiting factors in plant research. Alternatively, transient expression assays have been indispensable for rapid progress in functional genomics research in other model plants. For instance, the Arabidopsis mesophyll protoplast transient expression system is an efficient and useful system for characterizing genes and their functions. However, the use of such a mesophyll protoplast transient system for the model legume $P$. vulgaris is still in its 

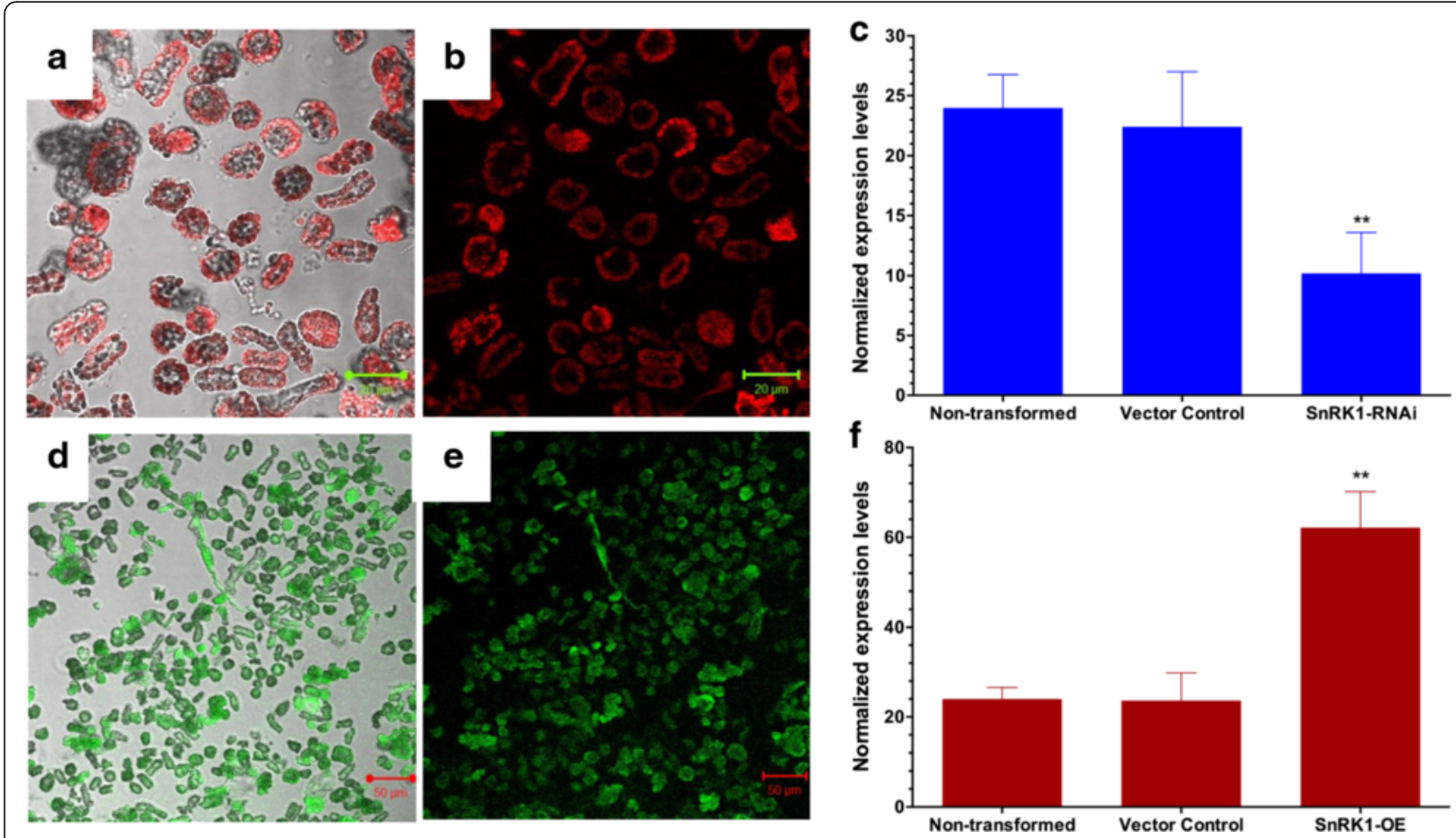

Fig. 4 Transformation and gene expression analysis of leaf mesophyll protoplasts of Phaseolus vulgaris. a-b Laser-scanning confocal microscope showing protoplasts that were transformed with the PVSnRK1-RNAi vector expressing red fluorescence. c Quantitative RT-PCR analysis showing the downregulation of the PVSnRK1 transcript in protoplasts that were transformed with the PVSnRK1-RNAi vector. $\mathbf{d}$-e Protoplasts that were transformed with the PVSnRK1-OE vector expressing green fluorescence under a laser scanning confocal microscope. f Quantitative RT-PCR analysis showing the overexpression of the SnRK1 transcript in protoplasts that were transformed with the PVSnRK1-OE vector. For RT-qPCR analysis, the total RNA was isolated from transformed protoplasts after $20 \mathrm{~h}$ of incubation at room temperature in the presence of light. Transcript accumulation was normalized to the expression of Ef1a and IDE, which were used as reference genes. The data are the averages of three biological replicates $(n>9)$. The statistical significance of the differences between the control (non-transformed and vector control) and transformed protoplasts was determined using a one-way ANOVA Newman-Keuls Multiple Comparison Test (**, $P<0.01$ ). The error bars represent means $\pm \mathrm{SD}$

infancy. The optimal plant growth conditions that are associated with highly efficient protoplast isolation, including the optimal enzyme concentration, the length of digestion, the protoplast yield, the percent transfection efficiency, and the use of the system for characterizing exogenously introduced gene(s), have not been previously reported.

The uniqueness of the current study is demonstrated in the procedures that were used to isolate good-quality protoplasts from Phaseolus leaves, flower petals, hypocotyls, roots and nodules. The recalcitrant nature of Phaseolus often makes it difficult to use in vitro suspension cultures. The techniques described here use pot-grown or germinated seedlings as opposed to cells from in vitro cultures [18]. Further, there is also an increased possibility that these protoplasts maintain their in planta physiology and responses to signal transduction. The key to the successful isolation of protoplasts from various tissues was the plant growth environment because some changes in environmental conditions such as, flooding, extreme temperature, drought and mechanical perturbation will decrease the yield and will also affect the transfection efficiency [10, 34]. The time that was needed for digestion varied depending on the tissue source, and this variation could be due to the changing cell wall composition across tissues. While isolating hypocotyls and nodule protoplasts, the preplasmolysis and osmolarity of the enzyme solution had a significant effect on the protoplast yield [35, 36]. Generally, protoplasts burst in hypotonic solution and collapse in hypertonic solution [37, 38] and in the present study, 9-13\% mannitol imposed appropriate osmotic pressure. The yield and viability of protoplasts are comparable to those of previous reports [39-41].

Thus, isolated protoplasts varied greatly in size and form depending on the tissue source. The protoplasts mostly remained spherical, except in the case of noduleinfected cells, which were heterogeneously shaped, in agreement with previous descriptions of infected protoplasts from determinate nodules [40, 42, 43].

Among the different methods for transfecting leaf mesophyll-derived protoplasts, the PEG-MMG method 


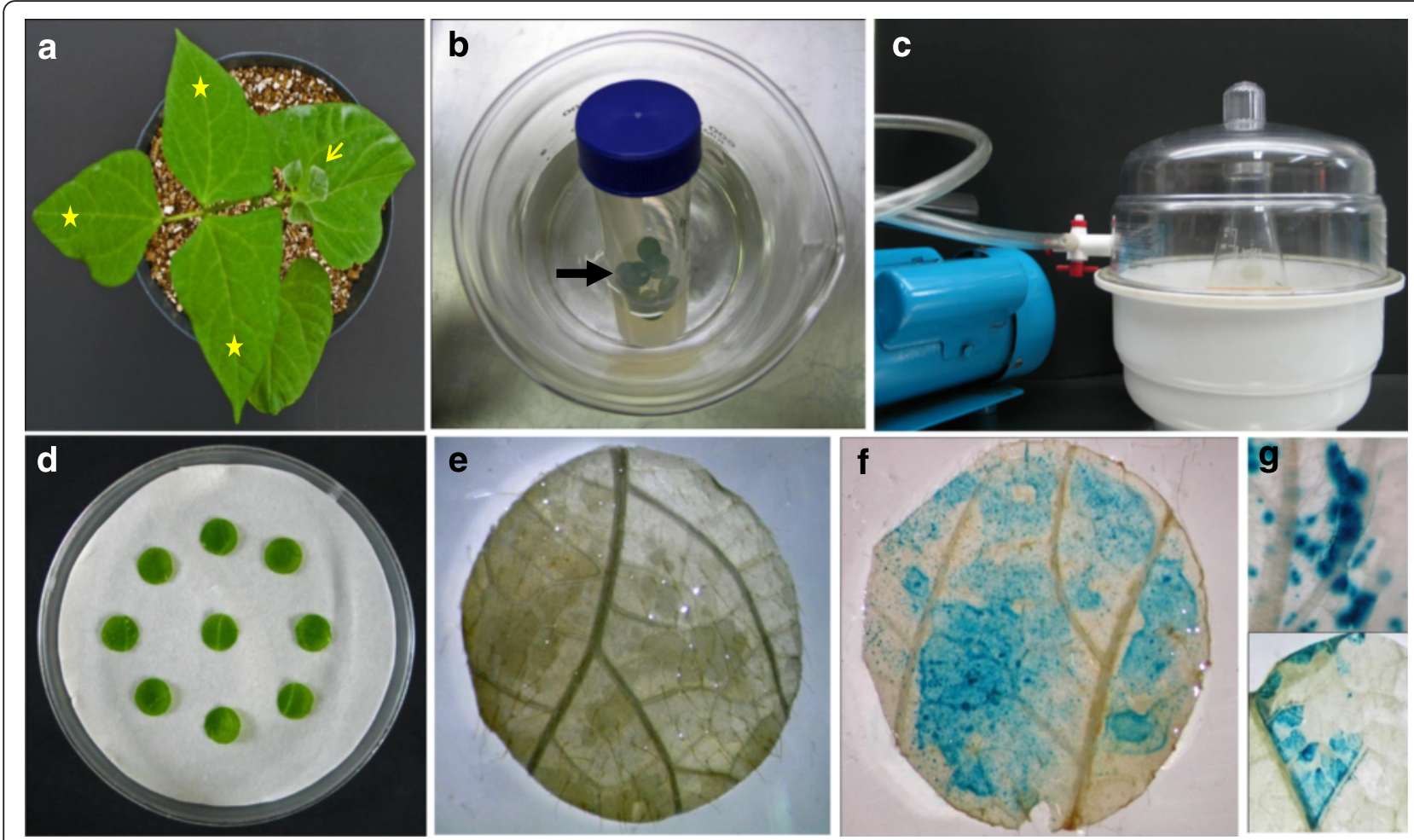

Fig. 5 Transient gene expression by the improved SAAT method in Phaseolus vulgaris using the pPZP-RCS-GUS binary vector. a Ten-day-old plant that was grown in a growth chamber showing the second trifoliates (asterisk) suitable for the transient assay. Arrow- first trifoliate (from shoot apex). $\mathbf{b}$ The leaf discs in the vir-gene-induced Agrobacterium culture were first subjected to sonication and $\mathbf{c}$ later vacuum infiltrated in fresh Agrobacterium culture. $\mathbf{d}$ Co-cultivation of Agrobacterium-infected leaf discs on sterile filter paper moistened with MS basal medium. e The leaf discs that were transformed with empty vector were stained for the histochemical localization of $\beta$-glucuronidase (GUS) reporter activity. No bluestained tissue appeared even after $24 \mathrm{~h}$ of incubation with the GUS assay buffer. $\mathbf{f - g}$ The leaf discs that were transformed with the pPZP-RCS-GUS vector were stained for the histochemical localization of $\beta$-glucuronidase (GUS) reporter activity. Blue staining appeared within $16 \mathrm{~h}$ of incubation

using 15-20 $\mu \mathrm{g}$ of plasmid DNA (pPZP-RCS-35S/intron GUS) and 40 \% PEG was optimal, with 90-95 \% transformed cells. This study demonstrates that Phaseolus protoplasts could be the system of choice when analyzing gene function either by RNAi or by overexpression. Because protoplasts are non-growing cells, effective RNAi-triggered gene silencing depends not only on the depletion of gene transcripts but also on the turnover rates of corresponding polypeptides. Herein, we tested whether transient RNAi in protoplasts results in the depletion of a targeted polypeptide using the PvSnRK1RNAi vector and also tested the feasibility of the ectopic, constitutive expression of PvSnRK1 in leaf mesophyll- derived protoplasts. The quantitative RT-PCR results showed that the protoplasts that were transformed with the PvSnRK1-RNAi and PvSnRK1-OE vectors significantly downregulated and ectopically overexpressed the PvSnRK1 transcript, respectively. The transfection of RNAi vectors in Arabidopsis and rice protoplasts decreases the transcript level of the targeted exogenous and endogenous genes [44, 45].

With the goal of standardizing the methodology for the transient transformation of $P$. vulgaris leaf disc infiltration by SAAT, several aspects were optimized: 1) the density of bacteria required to obtain efficient tissue transformation $[30,46], 2)$ Winan's AB medium

Table 2 Transfection efficiency of Phaseolus vulgaris leaf discs that were infiltrated by the SAAT method under different infiltration media

\begin{tabular}{llllll}
\hline Growth medium & Infiltration medium & Leaf discs & Transient & Efficiency transfection (\%) & Reference \\
\hline LB & $10 \mathrm{mM} \mathrm{MgCl}_{2}$ & 30 & 9 & 30 & [55] \\
LB & $10 \mathrm{mM} \mathrm{MgCl}$ and 5 mM MES-KOH & 30 & 15 & 50 & [56] \\
Winan's AB & Winan's AB & 30 & 27 & 90 & [54] \\
\hline
\end{tabular}

${ }^{*}$ Ten leaf discs were used per biological replicate 


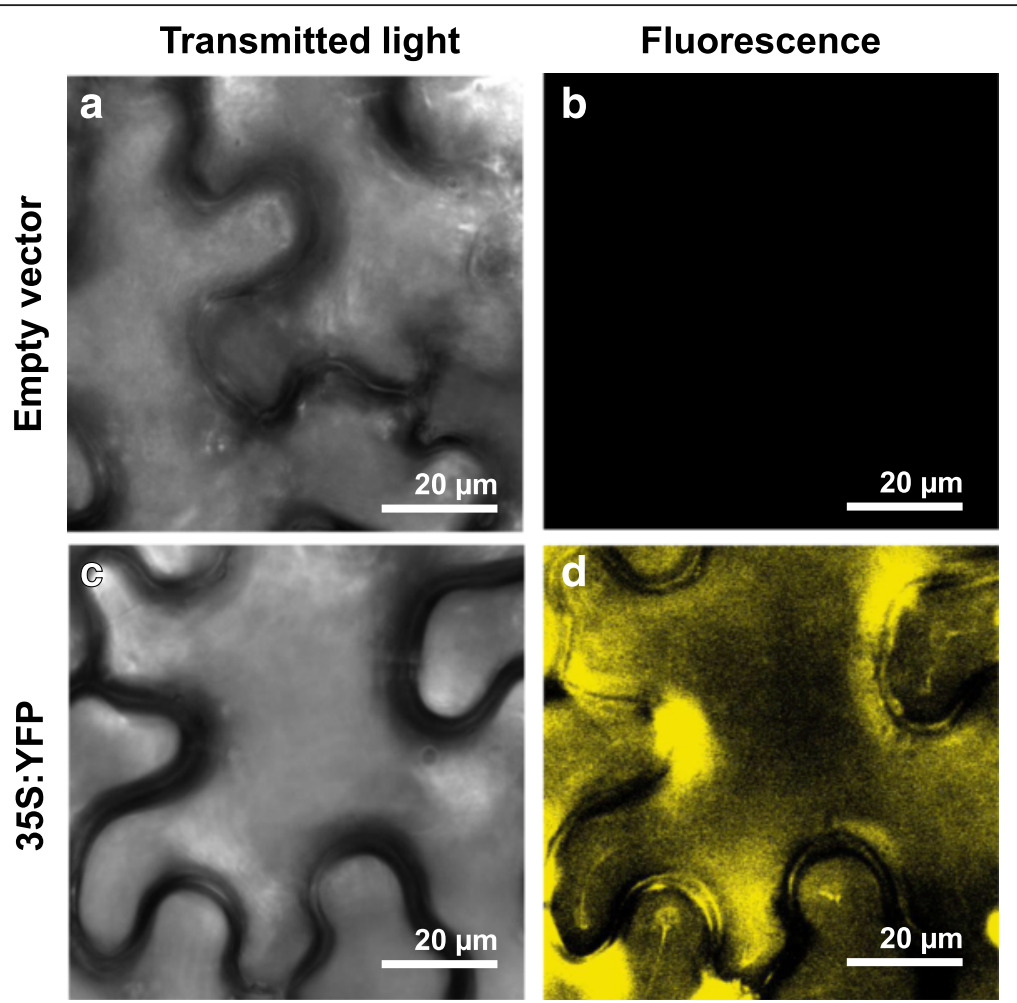

Fig. 6 YFP expression vector in leaf epidermal cells of Phaseolus vulgaris as delivered through the SAAT method. A representative confocal image showing the empty vector (control) of a pEarleyGate104-transformed leaf under $\mathbf{a}$ transmitted light and $\mathbf{b}$ fluorescent light. A representative confocal image showing the expression of the 35S:YFP vector in the leaf epidermis under $\mathbf{c}$ transmitted light and $\mathbf{d}$ fluorescent light

effectiveness among the different infiltration media [47], 3) the Silwet concentration, and 4) unlike the previous reports, the use of $5 \mu \mathrm{M}$ acetosyringone in an overnight bacterial culture in Winan's AB medium and the further addition of $100 \mu \mathrm{M}$ to the infiltration medium, ensuring highly efficient transformation resulting in approximately $60-85 \%$ of the leaf disc being transformed cells. Furthermore, we validated the system for the constitutive expression of the YFP gene and showed an intense fluorescent protein in the leaf epidermal cells. Thus, these results demonstrate that the modified SAAT leaf disc infiltration method is a simple, highly efficient and rapid process that is suitable for gene expression analysis.

\section{Conclusions}

In this study, we present protocols for the isolation of protoplasts from 5 different tissues of the model legume $P$. vulgaris. We also provide a high-efficiency and amenable method for leaf mesophyll transformation for gene functional characterization studies. Furthermore, we developed a modified SAAT leaf disc infiltration approach that aids in rapidly validating genes and their functions. These methods may help to rapidly unravel the functions of novel genes and represent promising tools for P. vulgaris research.

\section{Methods}

Plant material and growth conditions

In the present study, Phaseolus vulgaris L. cv Negro Jamapa was the source of all of the tissue material. The seeds were surface sterilized [8], and 2-day-old seedlings were grown either in sterile vermiculite or on sterile filter paper moistened with Broughton and Dilworth [48] (B\&D) nutrient solution in Petri dishes $(10 \mathrm{~cm}$ diameter) in a growth chamber at $26-28{ }^{\circ} \mathrm{C}, 65 \%$ humidity. The seedlings were irrigated on alternate days with $\mathrm{B} \& \mathrm{D}$ nutrient solution.

\section{Developing constructs for protoplast transformation}

For gene functional analysis in protoplast transient assays, we utilized the Phaseolus vulgaris SNF1-related protein kinase 1 (PvSnRK1) (Phvul.008G039400.1) gene (Fig. 7a) to develop RNA interference (RNAi) silencing (downregulating) or overexpression constructs. To generate the RNAi construct, a 209-bp fragment corresponding to the 3'-UTR of PvSnRK1 (Phvul.008G039400.1) was amplified from cDNA that had been isolated from common bean roots at 2 days post-germination, using the 


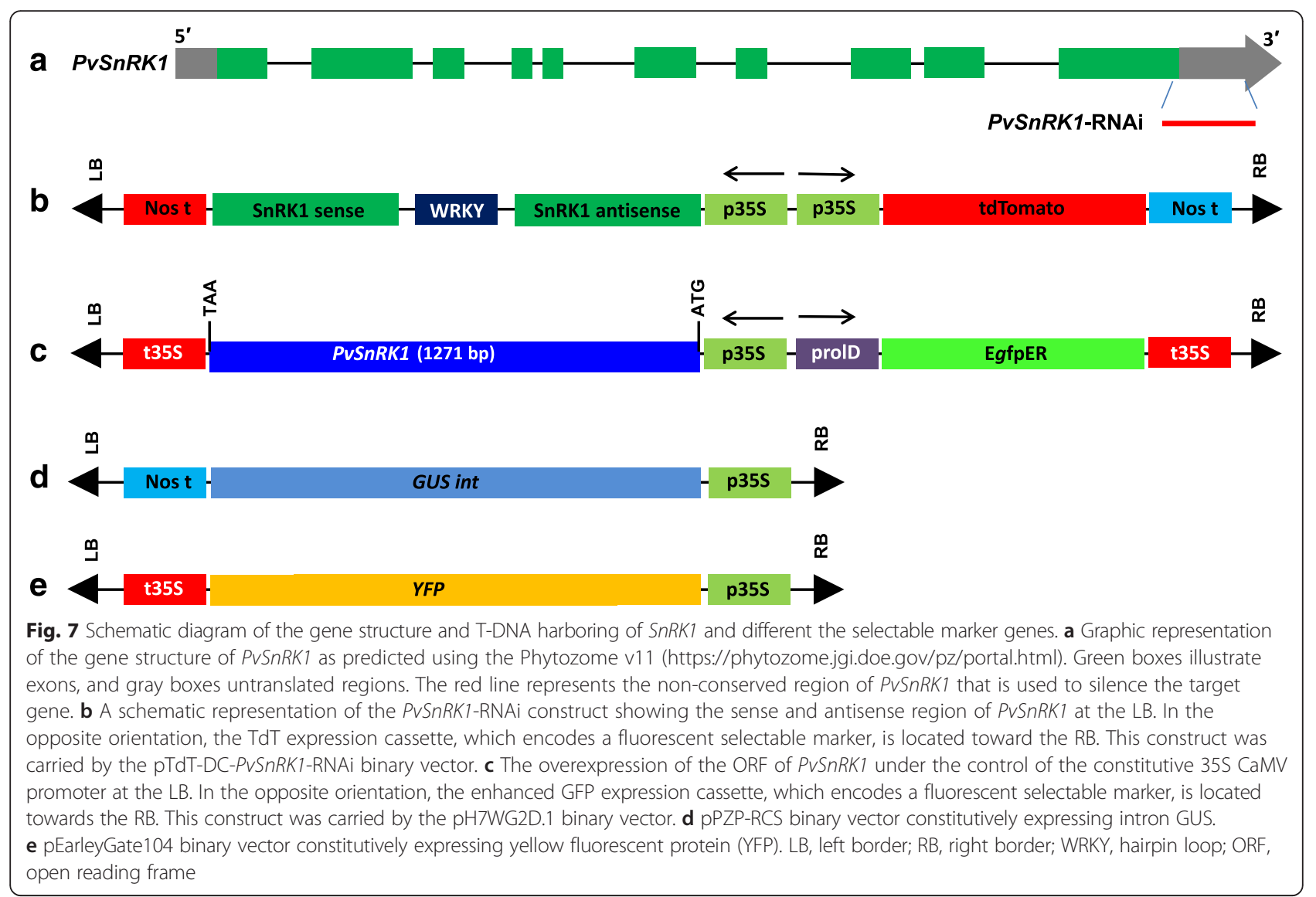

following primers: Forward 5'- CAC CAG ATC TAT GGA CGG ACC AGC TGG CCG-3' and Reverse 5'CTC GAG GAG GAC ACG AAG CTG TGC AAG G-3'. The PCR product was recombined with the pTdT-DCRNAi vector [49] using the Gateway System (Invitrogen) (Fig. 7b).

To develop an overexpression construct of PvSnRK1, the ORF of PvSnRK1 (Phvul.008G039400.1) from P. vulgaris cDNA was isolated, and the 1548 bp ORF fragment was inserted into the pH7WG2D.1 binary vector under the control of the constitutive $35 \mathrm{~S}$ promoter [50] using the Gateway System (Fig. 7c). The correct orientations of the clones were confirmed by sequencing the plasmid insert.

\section{Leaf mesophyll and flower petal protoplast isolation}

The first or second trifoliates from the shoot apical tip of ten-day-old plants were used for leaf mesophyll protoplast isolation (Fig. 1a). Standard and wing petals from fully bloomed flowers were used for flower petal protoplast isolation (Fig. 1b). Strips of $0.5-1 \mathrm{~mm}$ in thickness were cut from $1 \mathrm{~g}$ of both leaf and flower tissues from the portions shown in Additional file 1A, excluding the veins in the leaves. The leaf tissue strips were first vacuum infiltrated for $30 \mathrm{~min}$ in enzyme solution I [ES-I; $1.5 \%(\mathrm{w} / \mathrm{v})$ cellulase R10 (Yakult pharmaceutical industry) and $0.37 \%(\mathrm{w} / \mathrm{v})$ macerozyme R10 (Yakult pharmaceutical industry)] (Fig. 8a) and petal strips in ES-II [ES-I + $30 \mathrm{U}$ pectinase] in $20 \mathrm{mM}$ MES (pH 5.7) with $20 \mathrm{mM} \mathrm{KCl}, 0.4 \mathrm{M}$ mannitol and $10 \mathrm{mM} \mathrm{CaCl}_{2}$ (Fig. 8b). Later, the leaf tissue strips were digested in the dark on a horizontal shaker $(40 \mathrm{rpm})$ at $30{ }^{\circ} \mathrm{C}$ for $4-5 \mathrm{~h}$, whereas the flower petals were digested for 8-10 h. The enzymatic reaction was stopped by adding an equal volume of W5 solution [2 mM MES, $154 \mathrm{mM} \mathrm{NaCl}, 125 \mathrm{mM} \mathrm{CaCl}_{2}$ and $5 \mathrm{mM}$ $\mathrm{KCl}$ at $\mathrm{pH}$ 5.7]. The digested tissue was passed through $108 \mu \mathrm{m}$ mesh, and the filtrate was collected in a centrifuge tube and incubated on ice for $30 \mathrm{~min}$. Then, the cells were washed twice in W5 solution (10) at $100 \mathrm{~g}$ for $3 \mathrm{~min}$ each. The protoplast density was calculated using a hemocytometer. Finally, the protoplasts were resuspended in MMG solution (4 mM MES, 0.4 M mannitol and $15 \mathrm{mM} \mathrm{MgCl}_{2}$ at $\mathrm{pH}$ 5.7) (10) at the desired cell density.

\section{Hypocotyl and root protoplast isolation}

Protoplasts were isolated using the hypocotyl and root tip tissues (Fig. 1c-d) of three-day-old seedlings that were germinated on moistened filter paper. One gram of 

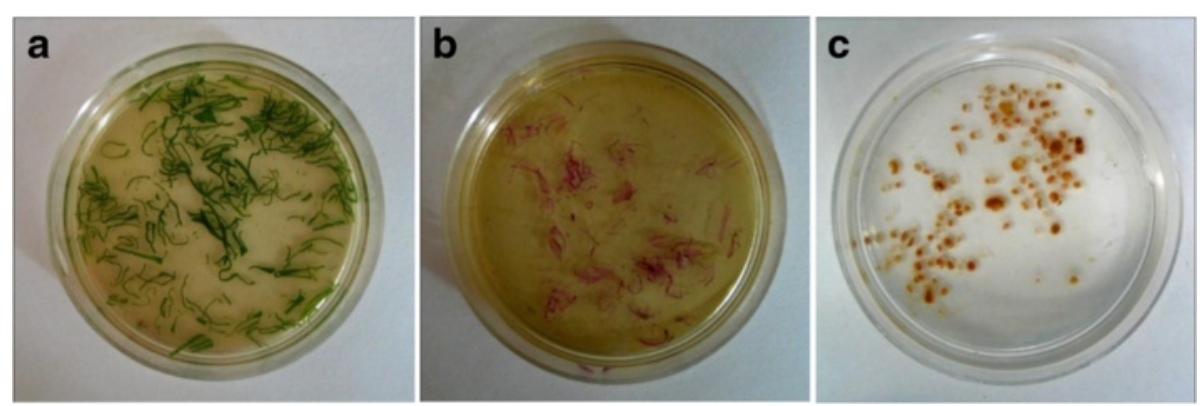

Fig. 8 Initial processing of Phaseolus vulgaris tissues for protoplast isolation. The plant material was sliced into 0.5-1 mm strips using a sterile scalpel blade and transferred to a Petri dish containing enzyme solution or medium for plasmolysis. a Leaf strips in enzyme solution. b Strips of wing and keel petals in enzyme solution. c Sliced nodules in plasmolysis solution

tissue was used to make 1-mm-thick fragments, which were plasmolysed sequentially in $9 \%$ and $13 \%$ mannitol in $\mathrm{CPW}$ solution $\left[\left(\mathrm{KH}_{2} \mathrm{PO}_{4}\left(27.2 \mathrm{mg} \mathrm{l} \mathrm{l}^{-1}\right), \quad \mathrm{KNO}_{3}\right.\right.$ $\left(100 \mathrm{mg} \mathrm{l}^{-1}\right), \mathrm{CaCl}_{2}\left(150 \mathrm{mg} \mathrm{l}^{-1}\right), \mathrm{MgSO}_{4}\left(250 \mathrm{mg} \mathrm{l}^{-1}\right)$, $\mathrm{Fe}_{2}\left(\mathrm{SO}_{4}\right)_{3} .6 \mathrm{H}_{2} \mathrm{O}\left(2.5 \mathrm{mg}^{-1} \mathrm{l}\right)$, KI $\left(0.16 \mathrm{mg} \mathrm{l}^{-1}\right)$ and $\mathrm{CuSO}_{4}$ $\left.\left(0.00025 \mathrm{mg} \mathrm{l}^{-1}\right) \mathrm{pH} 5.8\right]$ for $2 \mathrm{~h}$ each. The plasmolysed tissue was transferred to ES-III [2\% (w/v) cellulase R10, $0.3 \%(\mathrm{w} / \mathrm{v})$ macerozyme R10, and $4 \%(\mathrm{w} / \mathrm{v})$ hemicellulase in CPW with $13 \%$ mannitol] and incubated overnight in the dark on a horizontal shaker $(40 \mathrm{rpm})$ at $30^{\circ} \mathrm{C}$. The following day, the tissues were gently squeezed using sterile forceps to facilitate the release of protoplasts. To the solution of protoplasts, an equal volume of W5 solution was added, and the mixture was passed through $108 \mu \mathrm{m}$ mesh to remove the debris. At this stage, the cells were washed in W5 solution similar to the leaf mesophyll protoplasts and finally re-suspended in MMG solution at the desired hypocotyl (Fig. 2c) and root (Fig. 2d) protoplast density.

\section{Protoplast isolation from nodules}

Mature nodules that were harvested from $P$. vulgaris roots 18-21 days after inoculation with Rhizobium tropici expressing the GFP reporter were used for protoplast isolation (Fig. 1e; Additional file 1D). Approximately $500 \mathrm{mg}$ of fresh and healthy nodules (Fig. 1e) was excised from the roots and cut into $0.5-1 \mathrm{~mm}$ slices using a sterile razor (Additional file 1D). The nodule slices were plasmolysed in CPW with mannitol (Fig. 8c), similar to the hypocotyl and root tissues. The plasmolysed tissue was transferred to ES-IV [10 mM MES, $0.6 \mathrm{M}$ mannitol, and $1 \mathrm{mM} \mathrm{MgCl} 2$, with the addition of $1 \%(\mathrm{w} / \mathrm{v})$ cellulase R10, $0.3 \%(\mathrm{w} / \mathrm{v})$ macerozyme R10, $1 \%(\mathrm{w} / \mathrm{v})$ hemicellulase and $30 \mathrm{U}$ of pectinase at $\mathrm{pH}$ 5.7] and incubated overnight in the dark on a horizontal shaker $(40 \mathrm{rpm})$ at $30{ }^{\circ} \mathrm{C}$. Later, an equal volume of W5 solution was added to the digested tissue and passed through $108 \mu \mathrm{m}$ mesh. Uninfected (Fig. 2e) and infected (Fig. 2f-g) cells were further separated by passing the filtrate through $20 \mu \mathrm{m}$ mesh. At this point, the cells were washed twice in W5 solution by centrifugation at $100 \times g$ for $3 \mathrm{~min}$ each. Finally, the infected and uninfected cells were resuspended in MMG solution at the desired cell density.

\section{Leaf mesophyll protoplast transformation}

The pPZP-RCS::GUS [51] binary vector (Fig. 7d) was used to optimize the transformation conditions for $P$. vulgaris leaf mesophyll protoplast studies. The transformation steps were carried out either in a glass Petri plate or glass tube to avoid any loss due to protoplast adhesion. To introduce the plasmid DNA into protoplasts three different approaches such as electroporation, heat shock and PEG mediated transformation were used. Transformation by electroporation $(28,29)$ was carried out by varying the electrolytes $\left(\mathrm{KCl}, \mathrm{CaCl}_{2}, \mathrm{MgCl}_{2}\right)$, electric field $\left(250\right.$ or $300 \mathrm{~V} \mathrm{~cm}^{-1}$ ) and different capacitance $(10,33$ or $50 \mu \mathrm{F}) 2-3$ pulses for different durations ranging from $10 \mathrm{~s}$ to $15 \mathrm{~s}$ with an interval of $20 \mathrm{~s}$. In the heat shock method the protoplasts in CPW13 solution were combined with the plasmid DNA and the solution was exposed to $45{ }^{\circ} \mathrm{C}$ for $4-8 \mathrm{~min}$ followed by cooling on ice for $10 \mathrm{~min}$.

PEG mediated transformation was carried out employing the same protocol with $\mathrm{PEG}-\mathrm{CaCl}_{2}$ transfection buffer or PEG-MMG transfection buffers. For PEG mediated transformation, $200 \mu \mathrm{l}\left(\sim 2 \times 10^{5}\right)$ of protoplasts was pipetted into the center of the Petri plate, $10 \mu \mathrm{l}$ $(10-20 \mu \mathrm{g})$ of plasmid DNA (pPZP-RCS-35S-intron GUS) was added, and the plate swirled gently to mix. After incubating at room temperature for $5 \mathrm{~min}, 200 \mu \mathrm{l}$ of PEG (40 \% PEG 4000 prepared in MMG solution) was added and mixed gently, and the transfection mixture was incubated at room temperature for 15-20 min. The transfection mixture was diluted by adding $2 \mathrm{ml}$ of $0.45 \mathrm{M}$ mannitol at $2 \mathrm{~min}$ intervals until the total volume reached to $12 \mathrm{ml}$. The mixture was mixed carefully after every addition of mannitol. The transfection mixture was transferred to a suitable round bottom glass tube, and the protoplasts were pelleted at $100 \mathrm{~g}$ for 
$3 \mathrm{~min}$. The cells were re-suspended in $1 \mathrm{ml}$ of WI solution [4 mM MES containing $0.5 \mathrm{M}$ mannitol and $20 \mathrm{mM} \mathrm{KCl}$ at $\mathrm{pH}$ 5.7], transferred to 6- or 12-well tissue culture plates and incubated for 3-6 h under light at room temperature. To stain the transformed protoplast for GUS histochemical activity, the protoplasts were resuspended in GUS reaction buffer and incubated in the dark at $37{ }^{\circ} \mathrm{C}$ for 16-24 $\mathrm{h}$ according to Jefferson [38]. The GUS-stained cells were mounted with $40 \%$ glycerol in PBS (137 mM $\mathrm{NaCl}, 2.7 \mathrm{mM} \mathrm{KCl}, 4.3 \mathrm{mM} \mathrm{Na} 2 \mathrm{HPO}_{4}$, and $1.47 \mathrm{mM}$ $\mathrm{KH}_{2} \mathrm{PO}_{4}$ ) and observed under a microscope to assess the percent transformation. Gene functional analyses, such as the downregulation and overexpression of $P \nu S n R K 1$, were carried out using PvSnRK1-RNAi and PvSnRK1-OE binary vectors, respectively.

\section{RT-qPCR analysis}

The total RNA was isolated from frozen leaf mesophyllderived protoplasts using the RNeasy Plant Mini Kit according to the manufacturer's recommendations (Qiagen, USA). Genomic DNA contamination in RNA samples was eliminated by incubating the samples with RNase-free DNase $\left(1 \mathrm{U} \mathrm{\mu l}^{-1}\right)$ at $37^{\circ} \mathrm{C}$ for $15 \mathrm{~min}$ and then at $65{ }^{\circ} \mathrm{C}$ for $10 \mathrm{~min}$. The RNA integrity and concentration were determined by electrophoresis and a Nanodrop ND-2000 spectrophotometer (Thermo Scientifics), respectively. For qRT-PCR, $2 \mu \mathrm{g}$ of total RNA was used to synthesize cDNA.

Quantitative real-time PCR was performed using the iScript $^{\text {TM }}$ One-step RT-PCR Kit with SYBR ${ }^{\circ}$ Green, following the manufacturer's instructions, in an iQ5 Multicolor Real-time PCR Detection System (Bio-Rad). Each reaction was set up using 40 ng of RNA as the template. A control sample that lacked reverse transcriptase (RT) was included to confirm the absence of contaminant DNA. The relative gene expression levels were calculated using the $2^{-\Delta \mathrm{CT}}$ method, with $\triangle \mathrm{CT}=\mathrm{CTgene}-$ CTreference gene. P. vulgaris EF1 $\alpha$ and IDE were used as internal controls, as previously described [53, 54]. The relative expression values, normalized with two reference genes, were calculated as previously described [55]. The data are averages of two or three biological replicates, and each sample was assessed in triplicate. The expression of the genes that are listed in Additional file 5 was quantified using gene-specific oligonucleotides.

\section{Agrobacterium-mediated leaf disc infiltration with sonication}

Agrobacterium tumefaciens strain AGL1 carrying the binary vector pPZP-RCS::GUS or pEarleyGate104 (Fig. 7e) was used for the $P$. vulgaris leaf disc infiltration experiments. Different infiltration media, such as (i) $10 \mathrm{mM}$ $\mathrm{MgCl}_{2}$ [55], (ii) $10 \mathrm{mM} \mathrm{MgCl}$ and $5 \mathrm{mM} \mathrm{MES-KOH}$ (pH 5.6) [56] and (iii) Winan's AB medium (pH 5.6) [52] were used to test the SAAT method for $P$. vulgaris leaf disc transformation.

The Agrobacteria were grown on LB agar plates with the appropriate antibiotics for 16-18 h, after which a single colony from the plate was used to inoculate LB broth and further grown for $18 \mathrm{~h}$ at $28{ }^{\circ} \mathrm{C}$. An aliquot of $3 \mathrm{ml}$ from the overnight culture was used to inoculate $100 \mathrm{ml}$ of freshly prepared infiltration media, including $10 \mathrm{mM} \mathrm{MgCl}, 10 \mathrm{mM} \mathrm{MgCl} 2$ and $5 \mathrm{mM}$ MES-KOH, or Winan's $\mathrm{AB}$ minimal medium amended with the appropriate antibiotics and $5 \mu \mathrm{M}$ acetosyringone. The culture was further grown for $18 \mathrm{~h}$ on incubator shaker $(230 \mathrm{rpm})$ at $28{ }^{\circ} \mathrm{C}$. The $\mathrm{OD}_{600}$ was adjusted to $0.5-0.7$ with the appropriate media, and SAAT was performed. In the case of Winan's AB medium, the bacterial culture was divided into two halves, and $10 \mu$ liter $^{-1}$ Silwet L-77 (surfactant; Vac-In-Stuff, Lehle Seeds, USA) and $100 \mu \mathrm{M}$ acetosyringone were added (each to only one half of the culture). Bean leaf discs $(6-11 \mathrm{~mm})$ were immersed in one half of the bacterial culture, sonicated for $5 \mathrm{~min}$ and later transferred to the second half of the culture, followed by vacuum infiltration. Vacuum infiltration was carried out for 20-25 min with 2-3 abrupt breaks. Finally, the leaf discs were incubated in the same bacterial culture in the dark for $30 \mathrm{~min}$ at $28{ }^{\circ} \mathrm{C}$ on a horizontal shaker $(40 \mathrm{rpm})$. Following incubation, the leaf discs were washed 3-4 times in PBS and incubated for 24 h on moistened sterile filter paper towels at $28{ }^{\circ} \mathrm{C}$. Finally, the leaf discs were washed with PBS containing $250 \mu \mathrm{g} \mathrm{ml}^{-1}$ cefotaxime to remove the Agrobacterium and were incubated for another $24 \mathrm{~h}$ on wet paper towels at $28^{\circ} \mathrm{C}$ before further analysis.

\section{GUS histochemical assay and microscopy}

A GUS assay was performed according to Jefferson [38] by incubating the leaf mesophyll-derived protoplasts or Agrobacterium-infiltrated leaf discs in the dark at $37{ }^{\circ} \mathrm{C}$ for $16-24 \mathrm{~h}$. The $\beta$-glucuronidase activity was observed with a brightfield Zeiss Axioplan microscope equipped with DIC optics. Transformed leaf protoplasts expressing TdT (red) and GFP (green) fluorescence were mounted onto slides in $40 \%$ glycerol in PBS (pH 7.4) and observed on a ZEISS-LSM/510 confocal laser-scanning microscope. GFP and YFP fluorescence was excited with a blue argon ion laser $(488 \mathrm{~nm})$, and the emitted fluorescence was collected from 510 to $540 \mathrm{~nm}$. RFP fluorescence was excited at $561 \mathrm{~nm}$ by a solid-state laser, and emission was filtered using a band-pass filter of 640/50 $\mathrm{nm}$.

\section{Additional files}

Additional file 1: Selection of appropriate Phaseolus vulgaris tissue material for protoplast isolation. (A) Wing and keel petals were excised, retaining the pink-colored portions, for protoplast isolation. (B) The roots 
of 3-day-old germinated seeds were cut $3 \mathrm{~mm}$ from tip and were used for protoplast isolation. (C) Three-day-old germinating seeds were decotyledoned, and $\sim 10 \mathrm{~mm}$ hypocotyls were used to isolate protoplasts. (D) Sliced 18-dpi nodule that was inoculated with $R$. tropici harboring the pSN30-GFP plasmid expressing GFP fluorescence protein as seen under a laser scanning confocal microscope. Hc, hypocotyl; dpi, days post inoculation; dashed line, site of excision. (DOC $576 \mathrm{~kb}$ )

Additional file 2: pPZP-RCS-GUS vector-transformed leaf mesophyll protoplasts showing intense GUS expression. GUS staining could be detected within $16 \mathrm{~h}$ of incubation with GUS assay buffer. Scale bar: $20 \mu \mathrm{m}$. (DOC $181 \mathrm{~kb}$ )

Additional file 3: PCR-based detection of transgene integration in transformed protoplasts with PVSnRK1-RNAi or PVSnRK1-35S vector. To evaluate PVSnRK1-RNAi and PVSnRK1-35S vectors, oligos that were specific to 'Tdt' and 'gene-specific-p35S promoter and GFP' were used, respectively. gDNA that was isolated form transformed and untransformed leaf mesophyll protoplasts. Lane 1, Tdt; 2, SnRK1-35S; 3, GFP; M, molecular weight marker (1 kb); 4-6 are respective untransformed controls for 1-3. (DOC 56 kb)

Additional file 4: Percent transformation range and viability of mesophyll protoplast in various transformation methods. (DOC $33 \mathrm{~kb}$ )

Additional file 5: Primer sequences of Phaseolus vulgaris genes used to generate constructs and perform quantitative RT-PCR. (DOC $41 \mathrm{~kb}$ )

\section{Acknowledgements}

We thank Dr. Rosana Sánchez-López (IBT-UNAM) for critically reading the manuscript. The authors gratefully acknowledge the partial support of this work by PAPIIT (Dirección General de Asuntos del Personal AcadémicoUNAM) IN219916 to ML and IA205115 to MKA. This work was also supported by the Consejo Nacional de Ciencia y Tecnología, CONACYT-240614 to ML. We are grateful to the Centro de Ciencias Genómicas, UNAM, for providing the research facilities. We thank Xochitl Alvarado Affantrange (IBT-UNAM) and Victor Manuel Bustos Zagal (CCG, UNAM) for assistance with confocal microscopy and in the greenhouse, respectively.

\section{Funding}

This work was supported by Dirección General de Asuntos del Personal Académico (DGAPA-UNAM) for partially funding this research (Grant no IN219916 to ML and Grant no. IA205115 to MKA) and Consejo nacional de ciencia y tecnològia (CONACYT) (Grant no. 240614 to ML).

\section{Availability of data and material}

All the data obtained in this study are presented in the main body of this article and there are no supporting data available outside the main body of this article.

\section{Authors' contributions}

NK designed the project, conducted the experiments and analyzed the data. NK also wrote the preliminary manuscript. MKA was involved in technical support, microscopy, documentation and RT-qPCR analysis. LB isolated and cloned the PVSnRK1 gene into the RNAi binary vector. ESA assisted in the optimization of protoplast isolation. ML (corresponding author) conceived and coordinated the study, critically evaluated the data, and finalized the manuscript. All of the authors read and approved the final manuscript.

\section{Competing interests}

The authors declare that they have no competing interests.

\section{Consent to publication}

\section{Not applicable.}

\section{Ethics approval and consent to participate}

Not applicable.

\section{Author details}

'Ciencias Agrogenómicas, Escuela Nacional de Estudios Superiores, Universidad Nacional Autónoma de México (UNAM), León C.P.37684, Guanajuato, Mexico. ${ }^{2}$ Instituto de Fisiología Celular, Universidad Nacional Autónoma de México (UNAM), Ciudad Universitaria, Coyoacan, Ciudad de
México C.P. 62210, Mexico. ${ }^{3}$ Instituto Nacional de Salud Pública, Av. Universidad 655, Col. Santa Maria, Cuernavaca, Morelos 62100, Mexico. ${ }^{4}$ Instituto de Biología, Universidad Nacional Autónoma de México (UNAM), Ciudad Universitaria, Coyoacan, Ciudad de México C.P. 04510, Mexico.

Received: 22 April 2016 Accepted: 14 June 2016

Published online: 24 June 2016

\section{References}

1. Broughton WJ, Hernández G, Blair M, Beebe S, Gepts P, Vanderleyden J. Beans (Phaseolus spp.) - model food legumes. Plant Soil. 2003;252:55-128.

2. Beaver JS, Osorno JM. Achievements and limitations of contemporary common bean breeding using conventional and molecular approaches. Euphytica. 2009;168:145-75.

3. Popelka JC, Terryn N, Higgins TJV. Gene technology for grain legumes: can it contribute to the food challenge in developing countries? Plant Sci. 2004;167:195-206.

4. Hnatuszko-Konka K, Kowalczyk T, Gerszberg A, Wiktorek-Smagur A, Kononowicz AK. Phaseolus vulgaris - recalcitrant potential. Biotechnol Adv. 2014;32:1205-15.

5. Schmutz J, McClean PE, Mamidi S, Wu GA, Cannon SB, Grimwood J, Jenkins $J$, et al. A reference genome for common bean and genome-wide analysis of dual domestications. Nat Genet. 2014;46:707-13.

6. Rech EL, Vianna GR, Aragão FJL. High-efficiency transformation by biolistics of soybean, common bean and cotton transgenic plants. Nat Protoc. 2008:3:410-18.

7. Sticklen MB, Oraby HF. Invited review: shoot apical meristem: a sustainable explant for genetic transformation of cereal crops. In Vitro Cell Dev Biol. 2005;41:187-200.

8. Estrada-Navarrete G, Alvarado-Affantranger X, Olivares J, Guillén G, DíazCamino C, Campos F, Quinto C, Gresshoff PM, Sanchez F. Fast, efficient and reproducible genetic transformation of Phaseolus spp. by Agrobacterium rhizogenes. Nat Protoc. 2007;2:1819-24.

9. Sheen J. Signal transduction in maize and Arabidopsis mesophyll protoplasts. Plant Physiol. 2001;127:1466-75.

10. Yoo SD, Cho YH, Sheen J. Arabidopsis mesophyll protoplasts: a versatile cell system for transient gene expression analysis. Nat Protoc. 2007;2:1565-72.

11. Zhai Z, Sooksa-nguan T, Vatamaniuk OK. Establishing RNA Interference as a Reverse-Genetic approach for Gene Functional Analysis in Protoplasts. Plant Physiol. 2009;149:642-52.

12. Nishimura A, Aichi I, Matsuoka M. A protocol for Agrobacterium-mediated transformation in rice. Nat Protoc. 2006;1:2796-802.

13. Bhalla $\mathrm{PL}$, Singh MB. Agrobacterium-mediated transformation of Brassica napus and Brassica oleracea. Nature Proto. 2008;3:181-9.

14. Manavella PA, Chan RL. Transient transformation of sunflower leaf discs via an Agrobacterium-mediated method: applications for gene expression and silencing studies. Nature proto. 2009;4:1699-707.

15. Guo J, Morrell-Falvey JL, Labbe' JL, Muchero W, Kalluri UC, Tuskan GA, Jin-Gui C. Highly efficient isolation of Populus mesophyll protoplasts and its application in transient expression assays. Plos One. 2012;7:1-8.

16. Pitzschke A, Persak H. Poinsettia protoplasts - a simple, robust and efficient system for transient gene expression studies. Plant Methods. 2012;8:14.

17. Masani MYA, Noll GA, Parveez GKA, Sambanthamurthi R, Prüfer D. Efficient transformation of oil palm protoplasts by PEG-mediated transfection and DNA microinjection. Plos One. 2014;9:e96831.

18. Giovenazzo G, Greco V, Vitale A, Bollini R. Bean (Phaseolus vulgaris L.) protoplasts as model system to study the expression and stability of recombinant seed proteins. Plant Cell Rep. 1997;16:705-09.

19. Crepy L, Barros LMG, Valente VRN. Callus production from leaf protoplasts of various cultivars of bean (Phaseolus vulgaris L.). Plant Cell Rep. 1986;5:124-26

20. Veltcheva $M$, Svetleva D, Petkova S, Perl A. In vitro regeneration and genetic transformation of common bean (Phaseolus vulgaris L.) problems and progress. Sci Horticult. 2005;107:2-10.

21. Clough SJ, Bent AF. Floral dip: a simplified method for Agrobacteriummediated transformation of Arabidopsis thaliana. Plant J. 1998;16:735-43.

22. Yang Y, Li R, Qi M. In vivo analysis of plant promoters and transcription factors by agroinfiltration of tobacco leaves. Plant J. 2000;22:543-51.

23. Smith AM, Stitt M. Coordination of carbon supply and plant growth. Plant Cell Environ. 2007;30:1126-49. 
24. Purcell PC, Smith AM, Halford MG. Antisense expression of a sucrose nonfermenting 1 related protein kinase sequence in potato results in decreased expression of sucrose synthase in tubers and loss of sucrose-inducibility of sucrose synthase transcripts in leaves. Plant J. 1998;14:195-202.

25. Tiessen A, Prescha K, Branscheid A, Palacios N, McKibban R, Halford N, Geigenberger P. Evidence that SNF1-related kinase and hexokinase are involved in separate sugar-signalling pathways modulating posttranslational redox activation of ADP-glucose pyrophosphorylase in potato tubers. Plant J. 2003:35:490-500

26. Zhang $Y$, Shewry PR, Jones H, Barcelo P, Lazzeri PA, Halford NG. Expression of antisense SnRK1 protein kinase sequence causes abnormal pollen development and male sterility in transgenic barley. Plant J. 2001;28:431-42.

27. Radchuk R, Radchuk V, Weschke W, Borisjuk L, Weber H. Repressing the expression of the sucrose nonfermenting-1-related protein kinase gene in pea embryo causes pleiotropic defects of maturation similar to an abscisic acid-insensitive phenotype. Plant Physiol. 2006;140:263-78.

28. Bhaskar PB, Venkateshwaran M, Wu L, Ané JM, Jiang J. Agrobacterium mediated transient gene expression and silencing: a rapid tool for functional gene assay in potato. PLoS One. 2009;4:e5812.

29. Guerche P, Bellini C, Le Moullec JM, Caboche M, Guerche P, Bellini C, Le Moullec JM, Caboche M. Use of a transient expression assay for the optimization of direct gene transfer into tobacco mesophyll protoplasts by electroporation. Biochimie. 1987;69:621-28.

30. de Oliveira ML, Febres VJ, Costa MG, Moore GA, Otoni WC. High-efficiency Agrobacterium-mediated transformation of citrus via sonication and vacuum infiltration. Plant Cell Rep. 2009;28:387-95.

31. Díaz-Camino C, Annamalai P, Sanchez F, Kachroo A, Ghabrial SA. An effective virus-based gene silencing method for functional genomics studies in common bean. Plant Methods. 2011;13:7-16.

32. Wu H, Sparks C, Amoah B, Jones HD. Factors influencing successful Agrobacterium-mediated genetic transformation of wheat. Plant Cell Rep. 2003;21:659-68.

33. Montiel J, Nava N, Cárdenas L, Sánchez-López R, Arthikala MK, Santana O, Sánchez F, Quinto C. A Phaseolus vulgaris NADPH oxidase gene is required for root infection by Rhizobia. Plant \& Cell Physiol. 2012;53:1751-67.

34. Wu FH, Shen SC, Lee LY, Lee SH, Chan MT, Lin CS. Tape-Arabidopsis Sandwich - a simpler Arabidopsis protoplast isolation method. Plant Methods. 2009:5:16

35. Zhu L, Wang BC, Zhou J, Chen LX, Dai CY, Duan CR. Protoplast isolation of callus in Echinacea augustifolia. Colloids Surf B: Biointerfaces. 2005;44:1-5.

36. Tee CS, Lee PS, Kiong ALP, Mahmood M. Optimisation of protoplast isolation protocols using in vitro leaves of Dendrobium crumenatum (pigeon orchid) African. J Agric Res. 2010;5:2685-93.

37. Maeda E, Hagiwara T. Enzymatic isolation of protoplasts from the rice leaves and callus cultures. Proc Crop Sci Soc Jap. 1974:43:68-76.

38. Ohshima M, Toyama S. Studies on culture of cells and tissue of crop plants, I. survey on isolation and culture of protoplast from rice leaf sheath. Jap J Crop Sci. 1989;58:103-10.

39. Barros LMG, Valente VRN. Callus production from leaf protoplasts of various cultivars of bean (Phaseolus vulgaris L.). L Plant Cell Reports. 1986;5:124-6.

40. Pladys D, Dimitrijevic L, Rigaud J. Localization of a Protease in Protoplast Preparations in infected Cells of French Bean Nodules. Plant Physiol. 1991;97:1174-80.

41. Geerts P, Druart P, Ochatt S, Baudo JP. Protoplast fusion technology for somatic hybridisation in Phaseolus. Biotechnol Agron Soc Environ. 2008; 12:41-6.

42. Kouchi H, Fukai K, Hiroki K, Kiwamu M, Shigeyuki T. Isolation and enzymological characterization of infected and uninfected cell protoplasts from root nodules of Glycine max. Physiol Plant. 1988;73:327-34.

43. Kearns A, Whelan J, Young S, Elthon TE, Day DA. Tissue-specific expression of the alternative oxidase in soybean and siratro. Plant Physiol. 1992; 99:712-7.

44. An Cl, Sawada A, Fukusaki E, Kobayashi A. A transient RNA interference assay system using Arabidopsis protoplasts. Biosci Biotechnol Biochem. 2003;67:2674-7.

45. An Cl, Sawada A, Kawaguchi Y, Fukusaki E, Kobayashi A. Transient RNAi induction against endogenous genes in Arabidopsis protoplasts using in vitro-prepared double-stranded RNA. Biosci Biotechnol Biochem. 2005;69:415-8

46. Li JF, Park E, von Arnim AG, Nebenführ A. The FAST technique: a simplified Agrobacterium-based transformation method for transient gene expression analysis in seedlings of Arabidopsis and other plant species. Plant Methods 2009:5:6.

47. Manoj Kumar A, Reddy KN, Manjulatha M, Arellano ES, Sreevathsa R, Ganeshan G. A rapid and high-throughput identification of putative bell pepper transformants generated via in planta approach. Sci Horticult. 2011;129:898-903

48. Broughton WJ, Dilworth MJ. Control of leghaemoglobin synthesis in snake beans. Biochem J. 1971;125:1075-80.

49. Valdés-López O, Arenas-Huertero C, Ramírez M, Girard L, Sánchez F, Vance CP, Luis Reyes J, Hernández G. Essential role of MYB transcription factor: PVPHR1 and microRNA: PvmiR399 in phosphorus-deficiency signaling in common bean roots. Plant Cell Environ. 2008;31:1834-43.

50. Karimi M, Inzé D, Depicker A. Gateway vectors for Agrobacterium-mediated plant transformation. Trends Plant Sci. 2002;7:193-95.

51. Hajdukiewicz $P$, Svab Z, Maliga $P$. The small, versatile $p P Z P$ family of Agrobacterium binary vectors for plant transformation. Plant Mol Biol. 1994;25:989-94

52. Winans SC, Kerstetter RA, Nester EW. Transcriptional regulation of the virA and virG genes of Agrobacterium tumefaciens. J Bacteriol. 1988;170:4047-54.

53. Islas-Flores T, Guillén G, Alvarado-Affantranger X, Lara-Flores M, Sánchez F, Villanueva MA. PVRACK1 loss-of-function impairs cell expansion and morphogenesis in Phaseolus vulgaris L. root nodules. Mol Plant Microbe Interact. 2011;24:819-26.

54. Borges A, Tsai SM, Caldas DG. Validation of reference genes for RT-qPCR normalization in common bean during biotic and abiotic stresses. Plant Cell Rep. 2012:31:827-38.

55. Manavella PA, Chan RL. Transient transformation of sunflower leaf discs via an Agrobacterium-mediated method: applications for gene expression and silencing studies. Nat Protoc. 2009;4:1699-707.

56. Marion J, Bach L, Bellec Y, Meyer C, Gissot L, Faure JD. Systematic analysis of protein subcellular localization and interaction using high-throughput transient transformation of Arabidopsis seedlings. Plant J. 2008;56:169-79.

\section{Submit your next manuscript to BioMed Central and we will help you at every step:}

- We accept pre-submission inquiries

- Our selector tool helps you to find the most relevant journal

- We provide round the clock customer support

- Convenient online submission

- Thorough peer review

- Inclusion in PubMed and all major indexing services

- Maximum visibility for your research

Submit your manuscript at www.biomedcentral.com/submit 